\title{
A Full-Scale Field Study on Bearing Characteristics of Cast-in-Place Piles with Different Hole-Forming Methods in Loess Area
}

\author{
Zhijun Zhou $\mathbb{D}^{1}{ }^{1}$ Tao Yang $\mathbb{D}^{1},{ }^{1}$ and Haobo Fan $\mathbb{D}^{1,2}$ \\ ${ }^{1}$ School of Highway, Chang'an University, Xi'an, Shaanxi 710064, China \\ ${ }^{2}$ China Railway Eryuan Engineering Group Co.Ltd, Chengdu, Sichuan 610031, China \\ Correspondence should be addressed to Tao Yang; yangtao123@chd.edu.cn and Haobo Fan; fanhbjc@chd.edu.cn
}

Received 23 August 2018; Revised 10 December 2018; Accepted 4 February 2019; Published 30 April 2019

Academic Editor: Zahid Hossain

Copyright (C) 2019 Zhijun Zhou et al. This is an open access article distributed under the Creative Commons Attribution License, which permits unrestricted use, distribution, and reproduction in any medium, provided the original work is properly cited.

\begin{abstract}
This paper presents the results from a full-scale field study on the 3 different types of cast-in-place piles: rotary drilling piles (RDPs), manual digging piles (MDPs), and impact drilling piles (IDPs), for a bridge construction project of Wuqi-Dingbian Expressway, in Shaanxi. The results indicate that under the similar conditions, MDP exhibits the largest bearing capacity $(11000 \mathrm{kN})$ in the loess area, followed by RDP $(9000 \mathrm{kN})$ and IDP $(8000 \mathrm{kN})$. And all tested values exceed the estimated value $(7797.9 \mathrm{KN})$, indicating that the calculation formula of bearing capacity recommended by the Chinese standard is safe and conservative. During the load transfer process, the axial force attenuation rate of the pile body increases with pile side resistance. The average attenuation rate of MDP is the largest (24.2\%), followed by RDP (19.72\%) and IDP (16.69\%). The bearing characteristics of these test piles are mainly pile side resistance, but the manual digging method created the least amount of disturbance to the soil around the pile, and due to its hole wall being rough, this enhances the pile-soil interactions. Hole-forming methods mainly affect the exertion of pile side resistance compared with pile end resistance. In view of pile side resistance and pile end resistance not taking effect at the same time, degree of exertion of these 2 resistances should be considered when designing cast-inplace piles in loess areas, and different partial coefficients should be used.
\end{abstract}

\section{Introduction}

Pile foundations have been developed for thousands of years since the discovery of early pile foundation sites in the Republic of Chile. Up to now, pile foundations are also the most widely used building foundations or supporting structures [1-4]. When surface soils are too loose (soft) to support the shallow foundation safely and economically, such geotechnical structures can be used to better distribute the loads through the soil (friction piles) or transmit loads to a stronger soil layer at depths (end-bearing piles) [5-7]. As one of the most representative pile forms, cast-in-place piles are widely used in bridge and other engineering fields because of their great advantages (moderate cost, convenient construction, low construction noise, etc.) [8-12].

Loess is widely distributed in Asia $\left(74^{\circ} \mathrm{N}-32^{\circ} \mathrm{N}\right.$, based on data from Baidu Encyclopedia), especially in the central and western regions of China, where there is continuous development of China's economy and infrastructures in the promotion of the Belt and Road program; a large number of transportation networks are being built in the loess area, and cast-in-place piles will be widely used in this process. According to incomplete statistics, in China alone, the annual use of cast-in-place piles are at least 1 million or more [13-17]. Loess has strong structural characteristics. The construction of cast-in-place piles in the loess strata will inevitably destroy the structure of loess, which will affect the mechanical properties of loess and pile-soil relationship [18-21]. There are many research studies on the holeforming methods and loess in the cast-in-place pile foundation engineering, but the influences of hole-forming methods on the bearing capacity of pile foundation are not universal [22-27]. Meanwhile, the influence of holeforming methods on the bearing capacity of the pile 
foundation is also related to geological conditions, foundation forms, etc. Therefore, the influences of hole-forming methods on bearing characteristics of cast-in-place piles in the loess are uncertain and need further research [28-30].

Presently, the cast-in-place piles for bridge engineering in the loess area mainly include rotary drilling piles (RDPs), manual digging piles (MDPs), and impact drilling piles (IDPs) [31-34]. There are obvious differences between the piles with different hole-forming methods (as shown in Table 1) [35-38]. Many researchers [39-41] have analyzed the characteristics of these piles for different purposes; however, very few studies in the literature offer the side-byside comparison. Based on this, combined with the actual situation of Wuqi-Dingbian Expressway test area, static load tests of RDP, MDP, and IDP have been carried out. The influence of the hole-forming methods on the bearing characteristics of the cast-in-place piles is analyzed from the following aspects: (1) pile body settlement; (2) transfer law of axial force for the pile body; (3) distribution of the pile side resistance; and (4) exertion degree of pile end resistance.

\section{Structural Characteristics of Loess}

Structural characteristics are the intrinsic characteristic of soil. The structure of soil essentially includes the cementation and the composition (as shown in Figure 1). The former reflects the characteristics of soil skeleton connection while the latter reflects the geometrical and spatial characteristics of soil skeleton. Many research studies show that loess has strong structural characteristics [43-45]. Loess deformation is mainly elastic before its original microstructure is destroyed under certain disturbance, and its pore pressure is also elastic pore pressure, which has no effect on the effective stress of soil skeleton, so the strength of soil will not change greatly $[46,47]$. Once the structure of the soil has been destroyed, it will cause a series of adverse effects (such as the generation of plastic pore pressure, the decrease of effective stress, and the deterioration of mechanical properties). The construction of piles in loess will inevitably cause great disturbance and destroy the structure of loess, which will affect the mechanical properties of loess and the pile-soil relationship.

\section{Project Site and Subsoil Profile}

Wuqi-Dingbian Expressway (Figure 2) is located in Yan'an city and Yulin city, Shaanxi Province, China. The starting point of the expressway is located in Zoumatai, east of Wuqi County and ends in Shijingzi, southeast of Dingbian County. The expressway has an approximately total length of $92.22 \mathrm{~km}$ and is an important part of the $3 \mathrm{rd}$ vertical Dingbian to Hanzhong expressway in the network "2637" planned by Shaanxi Province. The abutments on both sides of the test area are located on the loess Liang-Mao region (the loess hilly area can be divided into 2 types according to its shape: the long strip is called "Liang" and the oval or round shape is called "Mao" (C) Baidu Encyclopedia), and the topographic relief of the abutment area is small. The ground elevation is $1629.60-1644.59 \mathrm{~m}$ with a relative height difference about $14.99 \mathrm{~m}$.
The groundwater in the test area is deeply buried, and there is no groundwater distribution in the depth of drill hole (the depth of drilling is $60 \mathrm{~m}$ ). According to the drilling results, soils in the test area are all in slightly wet and hard plastic state. Table 2 is the detailed characteristics of the soil in drill hole sampling.

\section{Static Load Test}

4.1. Bearing Capacity Estimation. To ensure the safety and reliability of the test, the bearing capacity of the pile (as shown in Table 3) was estimated by using formula (1) recommended in Chinese standard [48] before the test:

$$
Q_{\mathrm{uk}}=Q_{\mathrm{sk}}+Q_{\mathrm{pk}}=\mu \sum q_{\mathrm{sik}} l_{i}+\alpha p_{\mathrm{sk}} A_{p},
$$

where $Q_{\mathrm{sk}}$ is the total pile side resistance; $Q_{\mathrm{pk}}$ is the total pile end resistance; $\mu$ is the perimeter of pile body; $q_{\text {sik }}$ is the pile side resistance of the $i$-layer soil around the pile (the friction resistance is the pile side resistance in friction piles); $p_{\text {sk }}$ is the specific penetration resistance near the pile end, and its value can be directly determined in the standard [48], according to parameters (such as the soil properties, the diameter of pile, and the length of pile); $l_{i}$ is the length of the pile passing through each layer of soil; $\alpha$ is the correction coefficient of pile end resistance (when the pile length is between 10 and 30, $\alpha$ is interpolated between 0.75 and 0.90 according to the standard); and $A_{p}$ is the pile end area.

4.2. Test Design and Procedure. From Figure 3, it is noted that the roughness of every pile wall is different due to the different hole-forming methods. Compared with impact drilling method, the other 2 methods have less disturbance to the soil around the pile, and spade and rotary drilling rig continuously cut the soil in the hole, resulting in rough hole wall. And compared with IDP, the hole wall of MDP is rougher.

Referring to the Chinese standard [49], the on-site static load test (Figure 4) was carried out. The results of the test for 3 different types of cast-in-place piles (MDP, RDP, and IDP) have been compared and analyzed. The pile diameter and length of the 3 test piles were all $1.5 \mathrm{~m}$ and $25.0 \mathrm{~m}$. The diameter and the length of the anchor pile (AP) were $1.5 \mathrm{~m}$ and $30.0 \mathrm{~m}$ separately. The test piles were constructed with C30 concrete, and C40 concrete was used to reinforce the part $1.5 \mathrm{~m}$ away from the top of the piles. The anchor piles (APs) were all RDP, and all of them were cast by C30 concrete. The rebar used for the test piles was configured according to standard [49]. Meanwhile, 3 rows of rebar strain gauges were installed on the sides of the piles, and 7 rebar strain gauges were arranged in sequence along the pile at $0.5 \mathrm{~m}, 3.5 \mathrm{~m}, 6.5 \mathrm{~m}, 11 \mathrm{~m}, 15.5 \mathrm{~m}, 20.0 \mathrm{~m}$, and $24.5 \mathrm{~m}$ (Figure 5). The distance between 2 adjacent anchor piles was $7.0 \mathrm{~m}$, and the test piles were arranged in the center of the adjacent 4 anchor piles. The rebar used in the anchor piles was also configured according to the standard [49]. To fully study the bearing characteristics of test piles with different hole-forming methods, all 3 test piles were loaded to failure in field tests. 
TABLE 1: Comparison of all 3 types of cast-in-place piles.

\begin{tabular}{|c|c|c|c|c|}
\hline Type & Tool & Applicable condition & Advantage & Disadvantage \\
\hline $\begin{array}{l}\text { Rotary drilling } \\
\text { pile (RDP) }\end{array}$ & $\begin{array}{c}\text { Rotary } \\
\text { drilling rig }\end{array}$ & $\begin{array}{l}\text { Clay, silty soil, sand, artificial } \\
\text { filled soil }\end{array}$ & $\begin{array}{l}\text { The hole-forming speed is fast } \\
\text { and the quality is high; } \\
\text { construction site is clean. }\end{array}$ & $\begin{array}{l}\text { The weight of the equipment is } \\
\text { large and the construction } \\
\text { ground needs to be treated; need } \\
\text { to keep the head pressure in the } \\
\text { hole. }\end{array}$ \\
\hline $\begin{array}{l}\text { Manual digging } \\
\text { pile (MDP) }\end{array}$ & Man, spade & $\begin{array}{l}\text { The bearing stratum is above the } \\
\text { groundwater level, and the pile } \\
\text { diameter is } 800-2000 \mathrm{~mm} \text {. }\end{array}$ & $\begin{array}{c}\text { Strong bearing capacity of a single } \\
\text { pile; easy to clear holes and check } \\
\text { hole formation. }\end{array}$ & $\begin{array}{c}\text { It is difficult to make holes below } \\
\text { the groundwater level; there is a } \\
\text { great danger in the process of } \\
\text { digging holes. }\end{array}$ \\
\hline $\begin{array}{l}\text { Impact drilling } \\
\text { pile (IDP) }\end{array}$ & $\begin{array}{l}\text { Impact } \\
\text { drilling rig }\end{array}$ & $\begin{array}{l}\text { Clay, silty soil, sand layer, and } \\
\text { gravel soil layer }\end{array}$ & $\begin{array}{c}\text { Strong applicability; lower } \\
\text { platform requirements and lower } \\
\text { costs. }\end{array}$ & $\begin{array}{l}\text { The drilling efficiency is low; it is } \\
\text { difficult to make a circular hole; } \\
\text { accidents are easy to occur; the } \\
\text { depth and diameter of the hole } \\
\text { are small. }\end{array}$ \\
\hline
\end{tabular}

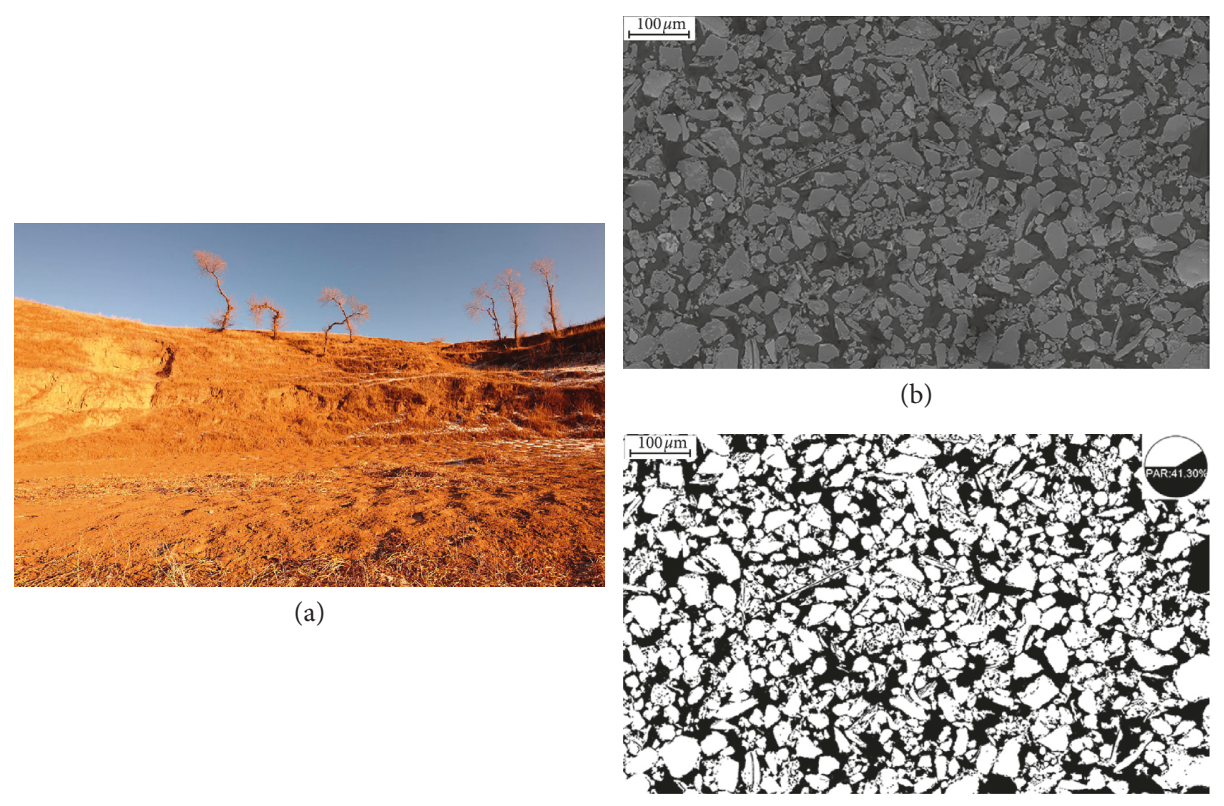

(c)

FIGURE 1: SEM image of loess (the pore area ratios are shown at the top right corners) [42]. (a) Loess. (b) Loess SEM image. (c) Loess SEM binary image.

\section{Analysis of the Test Results}

5.1. Ultimate Bearing Capacity of Single Pile. The Q-S curves of the 3 test piles, as shown in Figure 6, are overall steeply descending. And according to the standard [49], for such steeply descending Q-S curve, the inflection point is the ultimate bearing capacity. Therefore, the ultimate bearing capacities of MDP, RDP, and IDP are $11000 \mathrm{kN}, 9000 \mathrm{kN}$, and $8000 \mathrm{kN}$, respectively. The corresponding settlements are $10.89 \mathrm{~mm}, 7.22 \mathrm{~mm}$, and $3.35 \mathrm{~mm}$. The bearing capacities of the 3 test piles obtained from the test are all larger than the estimated value $(7797.9 \mathrm{kN})$, indicating that the bearing capacity estimated by the recommended formula (formula (1)) of the Chinese standard is safe and conservative. However, the bearing capacities of these piles are quite different, which further illustrates that different hole- forming methods will have different effects on the improvement of bearing capacity of cast-in-place piles.

The maximum load applied on the MDP, RDP, and IDP is $12000 \mathrm{kN}, 12000 \mathrm{kN}$, and $14000 \mathrm{kN}$, respectively. Meanwhile, the corresponding maximum settlements are $77.49 \mathrm{~mm}$, $72.86 \mathrm{~mm}$, and $63.9 \mathrm{~mm}$. With the removal of the upper load, the final settlement values of MDP, RDP, and IDP are $63.58 \mathrm{~mm}, 63.72 \mathrm{~mm}$, and $55.51 \mathrm{~mm}$, where the pile body rebound displacement of $\mathrm{MDP}$ is the largest $(13.91 \mathrm{~mm})$, followed by $\operatorname{RDP}(9.15 \mathrm{~mm})$ and IDP $(8.14 \mathrm{~mm})$. In the process of unloading on the pile top, the Q-S curves have been shown as a gentle rebound curve (Figure 6), indicating that the rebound value has a close relationship with the load applied on the pile top. The rebounds of settlement are mainly composed of elastic compression of the pile, followed by the back friction caused by the restoration of soil structure during 


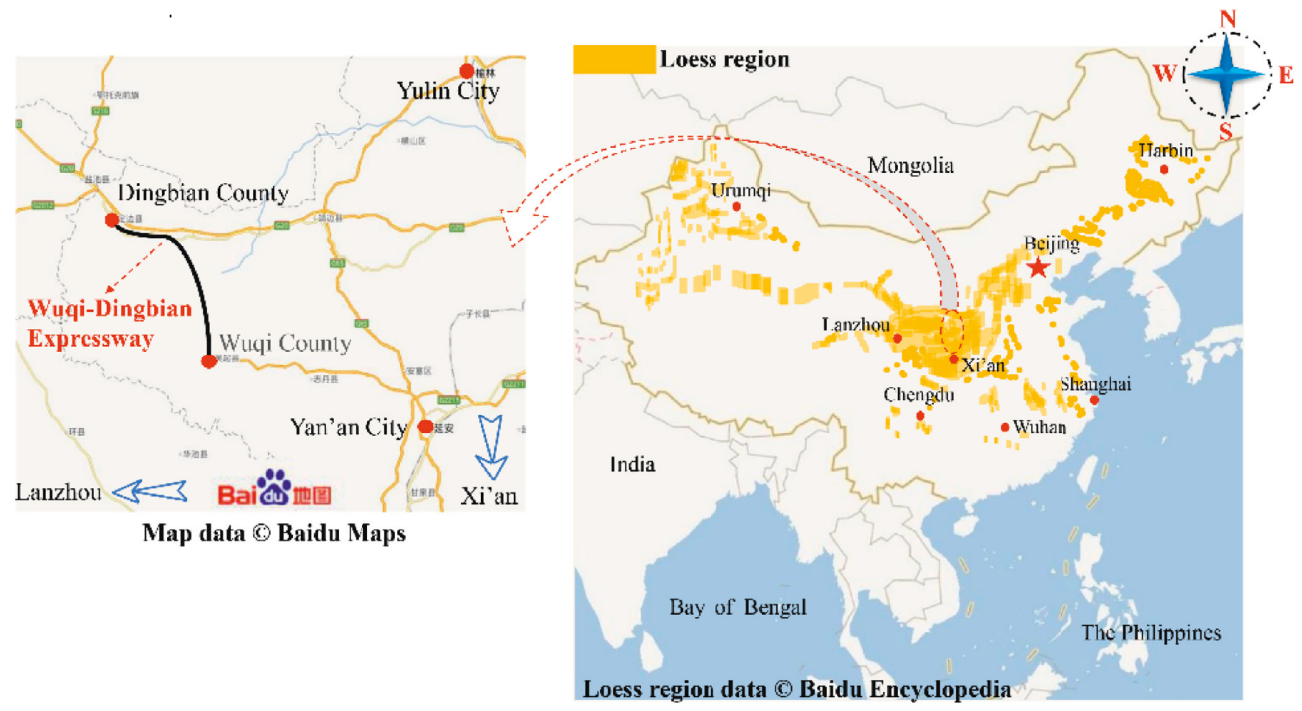

Figure 2: The location of Wuqi-Dingbian Expressway (map data ( 2018 Baidu Maps; loess region data (C Baidu Encyclopedia; expressway information data (c) from Shaanxi Provincial Department of Communications).

Table 2: Properties of the soil in the test area.

\begin{tabular}{lccccccc}
\hline Soil layer & Bottom depth $(\mathrm{m})$ & Layer thickness $(\mathrm{m})$ & Soil name & Colour & Soil distribution & $f_{\mathrm{a} 0}(\mathrm{kPa})$ & $q_{\mathrm{ik}}(\mathrm{kPa})$ \\
\hline \multirow{2}{*}{$\mathrm{Q}_{3}^{\text {eol }}$} & 5.9 & 5.9 & Loess & Tawny & Uniform soil & 120 & 50 \\
& 8.6 & 2.7 & Paleosol & Brownish red & Blocky structure & 170 & 60 \\
\hline \multirow{2}{*}{$\mathrm{Q}_{2}^{\text {eol }}$} & 23.0 & 14.4 & Loess & Tawny & Uniform soil & 240 & 55 \\
\hline $\mathrm{Q}_{2}^{\text {al+pl }}$ & 27.9 & 4.9 & Paleosol & Brownish red & Aggregate structure & 270 & 60 \\
\hline
\end{tabular}

$f_{\mathrm{a} 0}$ is the bearing capacity of soil strata and $q_{\mathrm{ik}}$ is the friction resistance.

TABLE 3: Estimation of bearing capacity for the test piles.

\begin{tabular}{lcccc}
\hline Stratum & $\begin{array}{c}Q_{3}^{\text {eol }} \\
(\text { loess })\end{array}$ & $\begin{array}{c}Q_{3}^{\text {eol }} \\
\text { (paleosol) }\end{array}$ & $\begin{array}{c}Q_{2}^{\text {eol }} \\
\text { (loess) }\end{array}$ & $\begin{array}{c}Q_{2}^{\text {eol }} \\
\text { (paleosol) }\end{array}$ \\
\hline$l_{i}(\mathrm{~m})$ & 5.9 & 2.7 & 14.4 & 2 \\
$q_{\text {sik }}(\mathrm{kPa})$ & 50 & 60 & 55 & 60 \\
\hline$Q_{\mathrm{sk}}(\mathrm{kN})$ & \multicolumn{5}{c}{6447.9} \\
$Q_{\mathrm{pk}}(\mathrm{kN})$ & \multicolumn{4}{c}{1350} \\
$Q_{\mathrm{uk}}(\mathrm{kN})$ & \multicolumn{5}{c}{7797.9} \\
\hline
\end{tabular}

the dissipation of frictional forces between piles and soils [50-53].

5.2. Transfer and Attenuation of Axial Force. By analysis of the field test data, the distribution of axial forces for MDP, RDP, and IDP is shown in Figures 7-9, respectively. Along the pile body, the regularities of distribution for these test piles are basically the same, which gradually decrease from top to bottom. And under the similar load, pile end resistance of IDP is the largest, followed by RDP and MDP. The results suggest that IDP has the best effect of pile end resistance, while, for MDP, pile side resistance exerts the best effect.

Under the action of axial load, the pile top will generate axial displacement (settlement), which is the sum of elastic compression of pile body and soil compression of pile end. When the pile moves downward relative to soil, pile side frictional resistance acting upward on the pile will generate. In the process of load transferring downward along the pile body, the friction must be overcome continuously, which leads to the decrease of the axial force of the pile body with the increasing strata depth. When the axial force is transferred to the pile end, the axial force will be balanced by the pile end soil support. The axial force attenuation rate represents the effect of pile side resistance, and the effect of pile side resistance increases with the axial force attenuation rate.

The attenuation rates of the axial forces of these piles are approximately the same. It is assumed that the axial force attenuation rate of the test pile is $v$ :

$$
v=\frac{1}{n} \sum_{i=1}^{n} \frac{p_{i}-p_{i+1}}{p_{i}} \times 100 \%,
$$

where $p_{i}$ is the axial force on the $i$ section of pile body; $p_{i+1}$ is the axial force on the $i+1$ section of pile body; and $n$ is the number of rebar meter.

Formula (2) can be used to calculate the axial force attenuation rates of these test piles, as shown in Figure 10. The variations of the axial force attenuation rates for these test piles are basically the same under all levels of load: all decreasing firstly, then increasing and decreasing lastly. The maximum, minimum, and average attenuation rates of axial force for MDP, RDP, and IDP are $26.13 \%, 21.22 \%$, and $18.4 \% ; 20.5 \%, 17.22 \%$, and $14.53 \%$; and $24.2 \%, 19.72 \%$, and $16.69 \%$, respectively. 


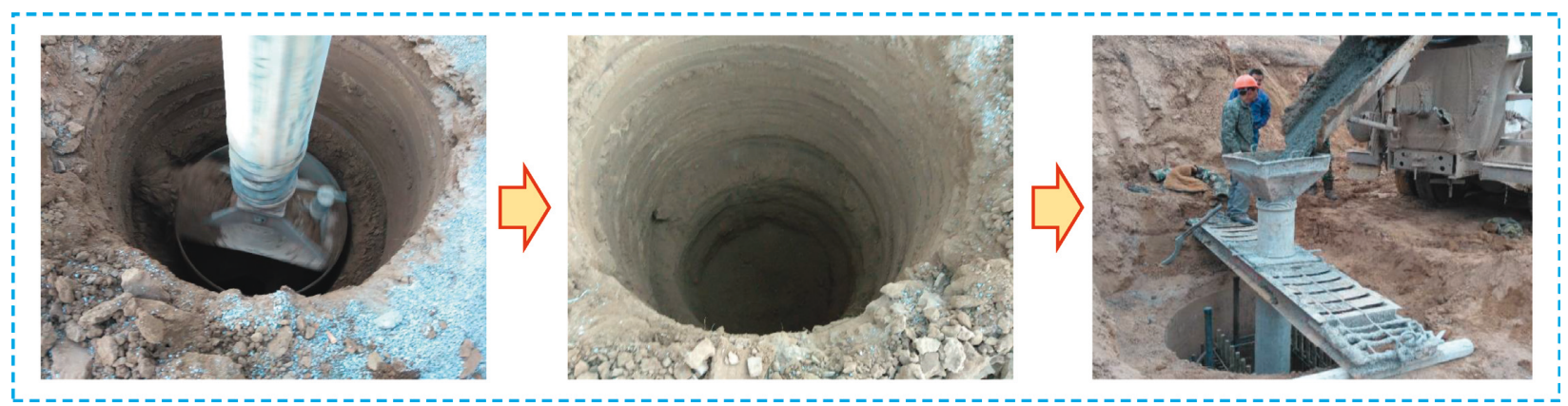

(a)

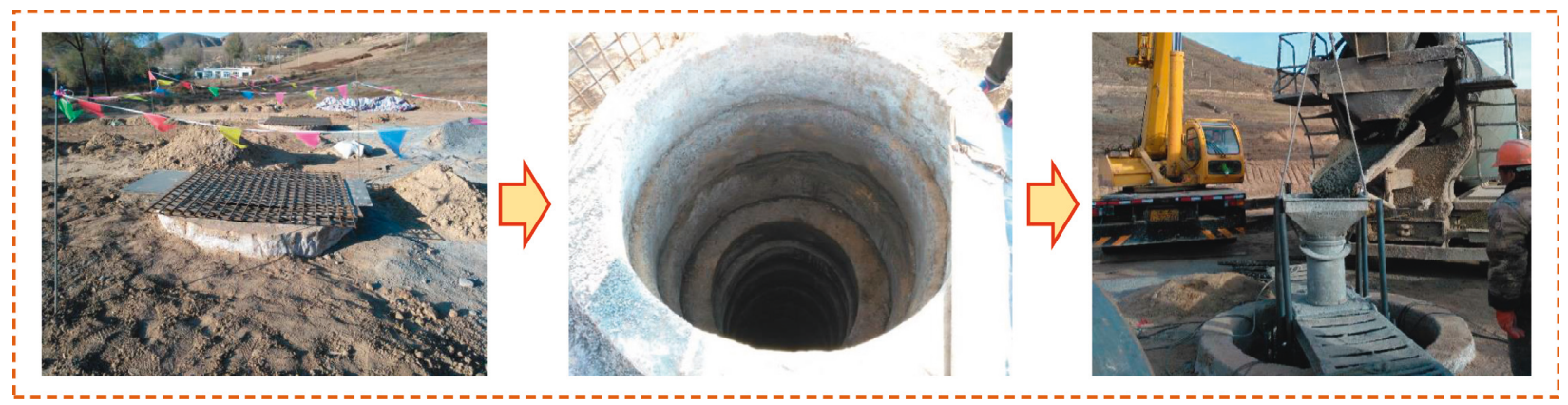

(b)

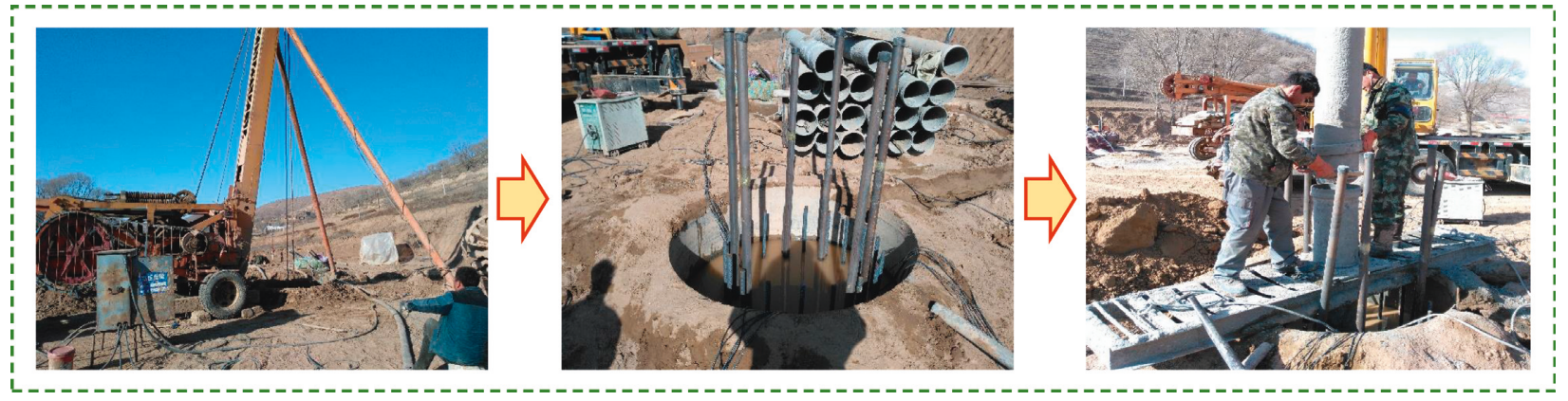

(c)

FIgURE 3: Construction process of the 3 test piles. (a) RDP. (b) MDP. (c) IDP.

\subsection{Pile Side Friction Resistance Distribution}

5.3.1. Distribution along the Pile Body. Under the similar load conditions, pile side resistances of these test piles level vary in different sections of their pile bodies (Figures 11-13). However, along their pile bodies, these pile side resistances' variations are roughly the same: all increase firstly and then decrease. Pile side resistances of all test piles reach the peak at the section of $11 \mathrm{~m}$ from the top of the pile and then the curve of IDP reaches the second peak at the bottom of the pile body. The peaks of these curves are related to the characteristics of the soil around the pile and pile-soil interactions [54-57].

As shown in Figure 14, when the load applied to the pile top is same, pile side resistance of MDP is the largest, followed by RDP and IDP. The result suggests that the concrete protection wall of MDP is conducive for the development of pile side resistance and enhancement of pile-soil interactions. Meanwhile, IDP will form a $2-3 \mathrm{~mm}$ thick mud cake around the pile during the construction process, which reduces the pile-soil interactions and is not conducive to the exertion of pile side resistance.

5.3.2. The Relationship between Pile Side Resistance and PileSoil Relative Displacement. As shown in Figure 15, when the pile-soil relative displacements are less than $5 \mathrm{~mm}$, pile side resistances of these test piles increase sharply with the displacements; however, as the relative displacements continue to increase, pile side resistances of these test piles increase slowly. When the relative displacements are the same, the MDP has the largest pile side resistance, followed by RDP and IDP.

\subsection{Effect of Pile End Resistance}

5.4.1. Pile End Resistance under Various Loads. From Figure 16, the pile end resistances of these test piles increase with the upper loads. And under the similar load, IDP's pile end resistance is the largest, followed by RDP and MDP. This 


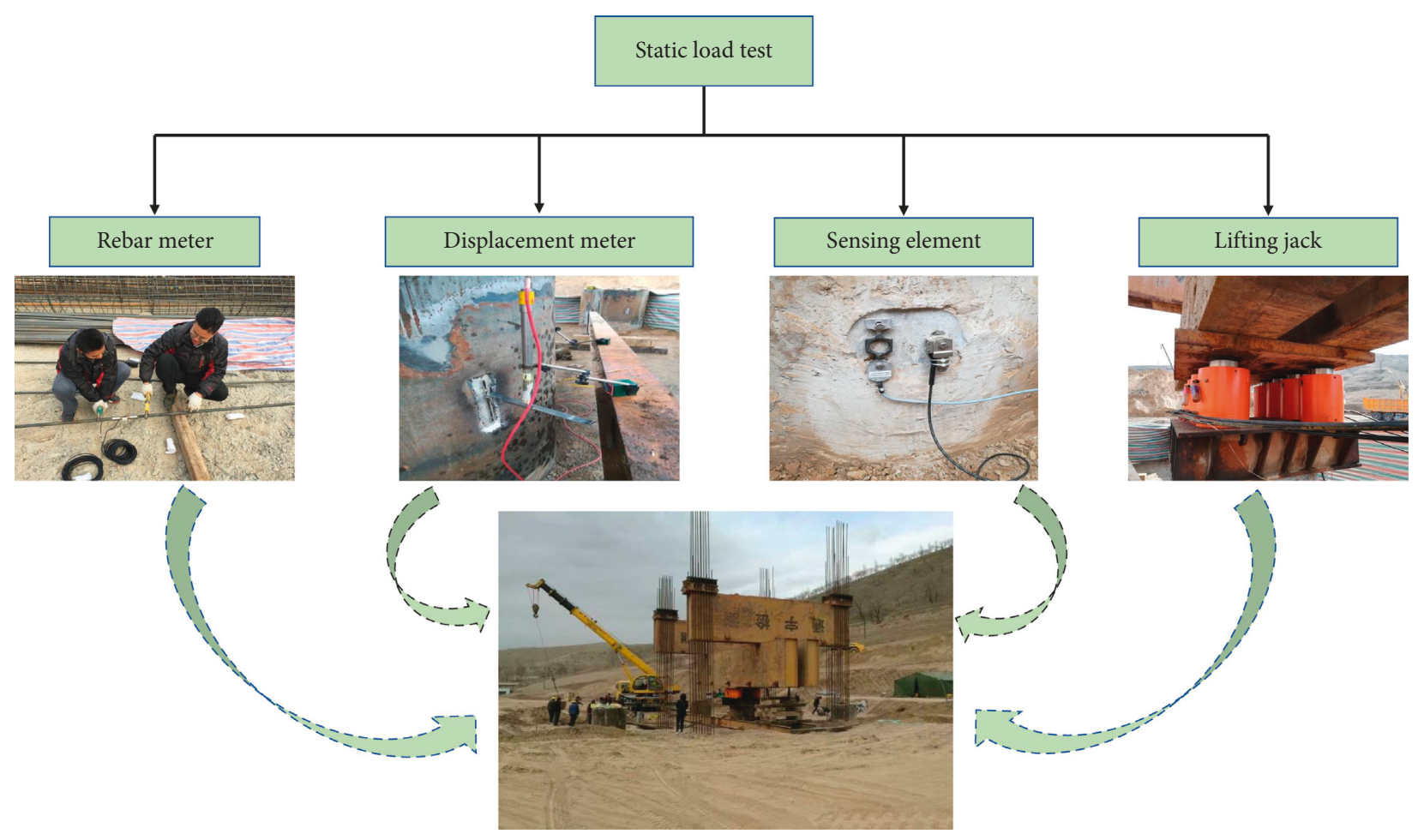

Figure 4: Static load test.

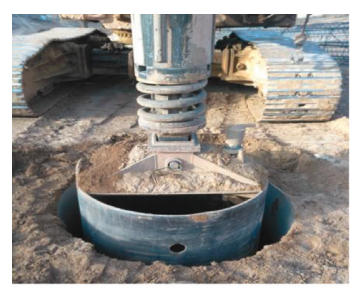

Rotary drilling pile (RDP)

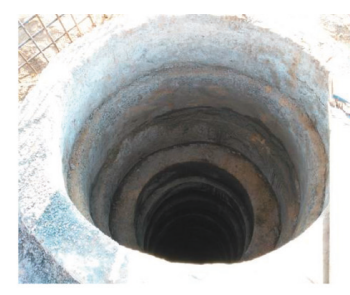

Manual digging pile (MDP)

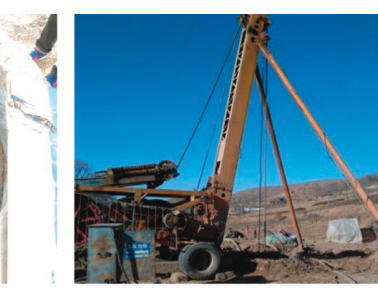

Impact drilling pile (IDP)
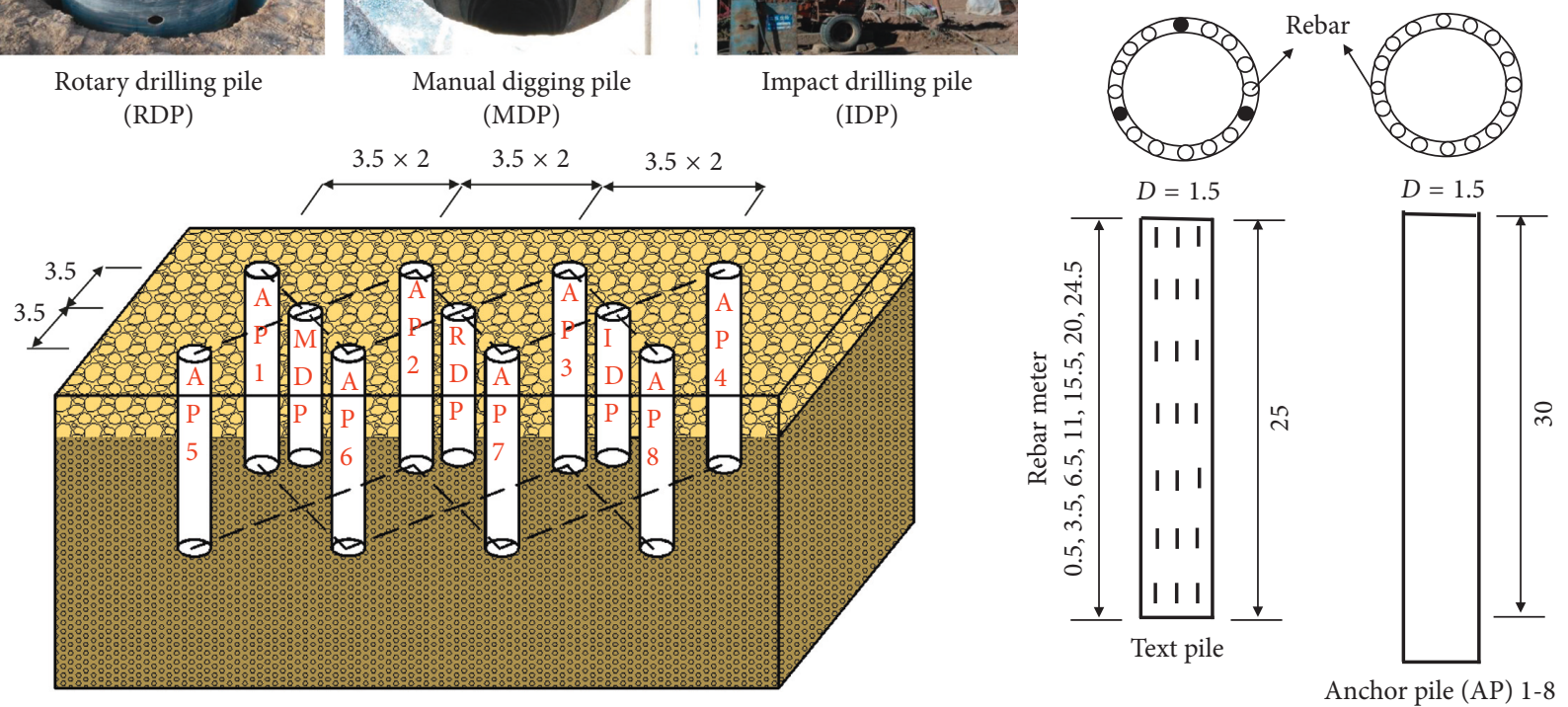

FIgURe 5: Layout of the test site (unit: m).

indicates that during the process of applying load, the ratio of pile end resistance for IDP is larger than the other 2 piles in the total resistance, and pile end resistance has the greatest impact on IDP.
5.4.2. Pile End Resistance under Ultimate Bearing Capacity. From the static load test, all the pile side resistances and pile end resistances of these test piles in the ultimate bearing capacity state are obtained, respectively. As illustrated in 


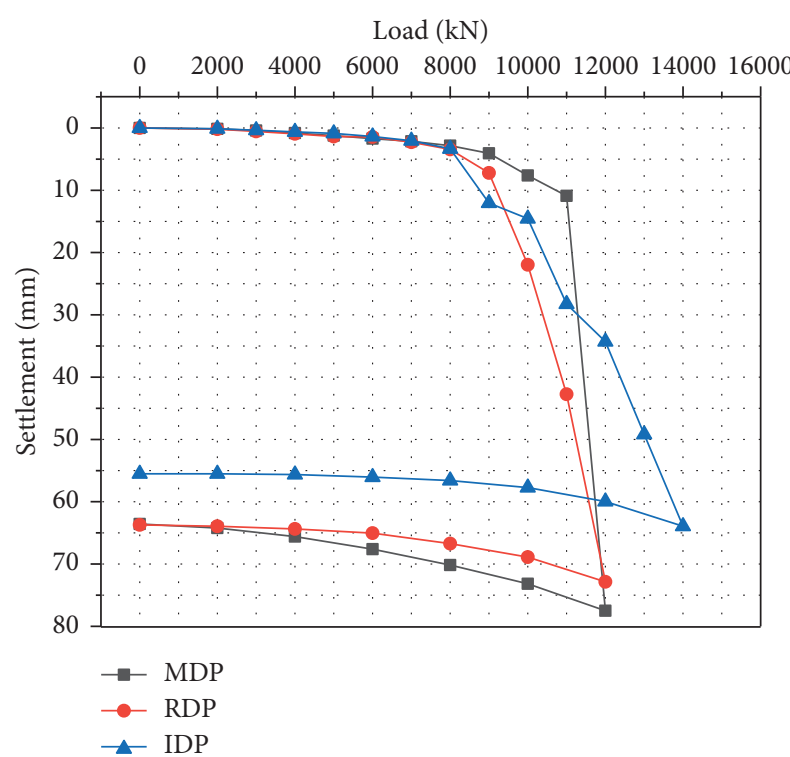

Figure 6: The Q-S curves of test piles.

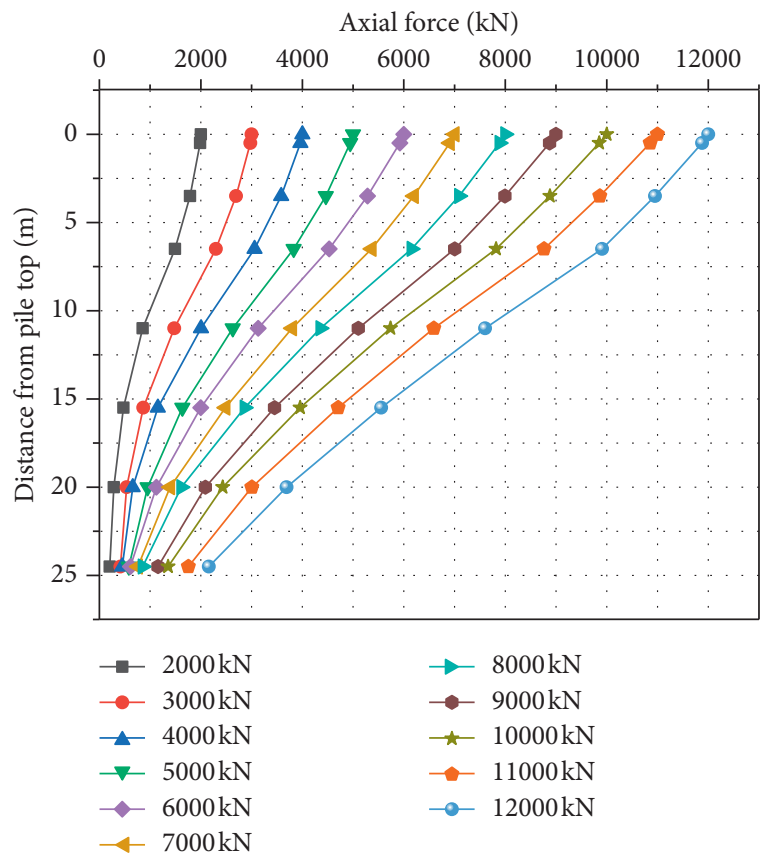

FIgURE 7: The axial force of MDP.

Table 4, when every test pile reaches the ultimate bearing capacity, the ratios of pile side resistance to pile end resistance are not the same. MDP has the largest ratio of pile side resistance in total resistance, followed by RDP and IDP, while the ratio of pile end resistance is on the contrary. Although the bearing characteristics of these 3 test piles are mainly depending on the pile side resistance, the degree of exertion of pile side resistance and pile end resistance in the 3 test piles is not the same.

5.4.3. The Change Law of Pile End Resistance with Pile Settlement. Due to the very small compression deformation

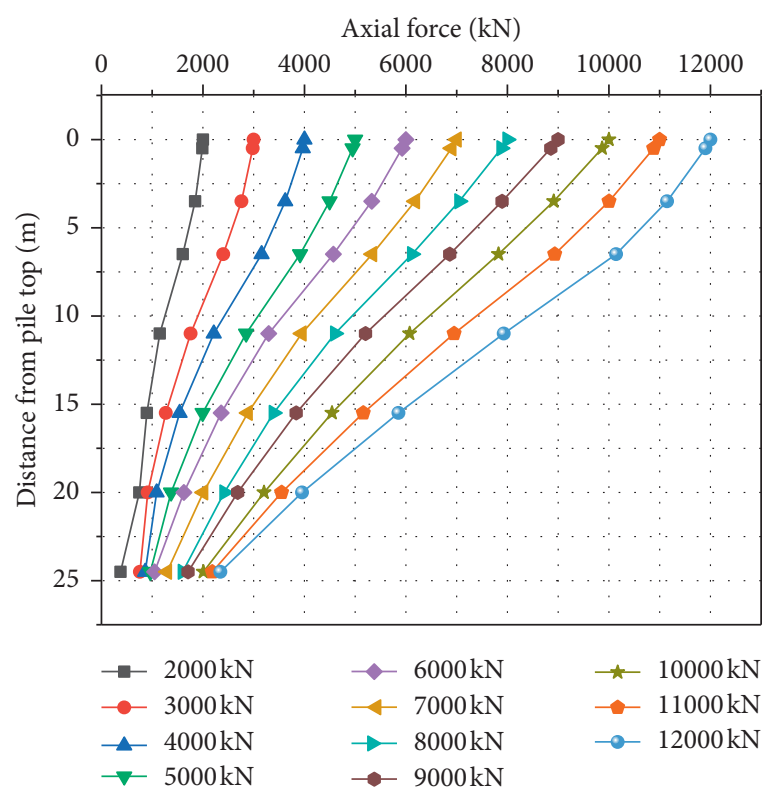

Figure 8: The axial force of RDP.

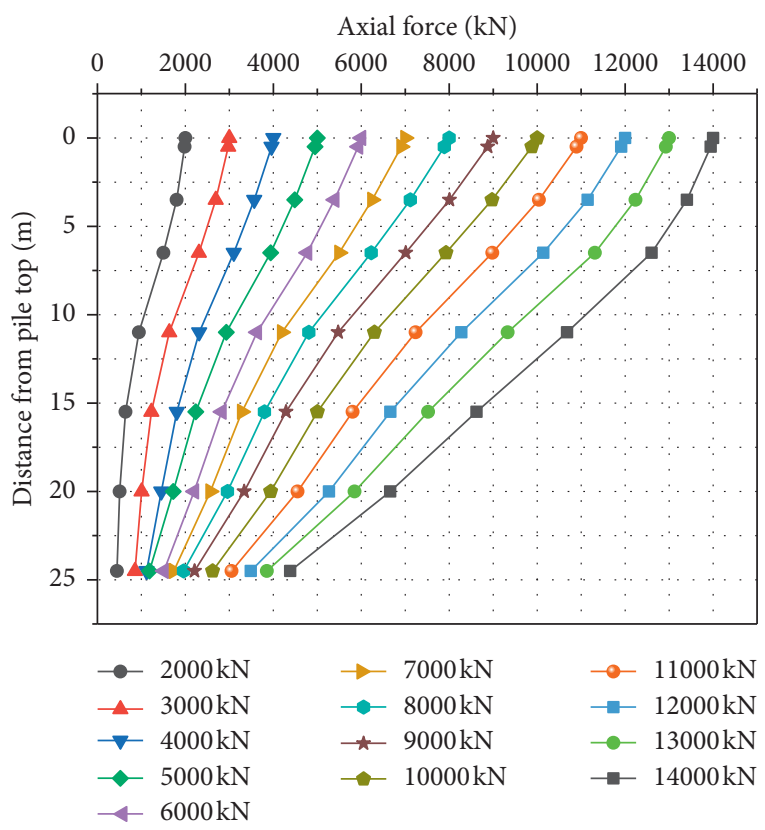

Figure 9: The axial force of IDP.

of the test piles, the settlement of pile top is used as the settlement of piles in this paper. From Figure 17, it is noted that when the settlements of the 3 test piles are the same, pile end resistance of IDP is the largest, followed by RDP and MDP. With the increase of the pile settlements, the pile end resistances of 3 test piles increase continuously. And among them, pile end resistance of IDP increases the most, but pile end resistances of the 3 test piles do not tend to a definite value. It shows that pile end resistance does not reach the limit value during the process of applying the load at the pile top. When the settlements of piles are less than $5 \mathrm{~mm}$, the differences in pile end resistances of the 3 test piles are small. 


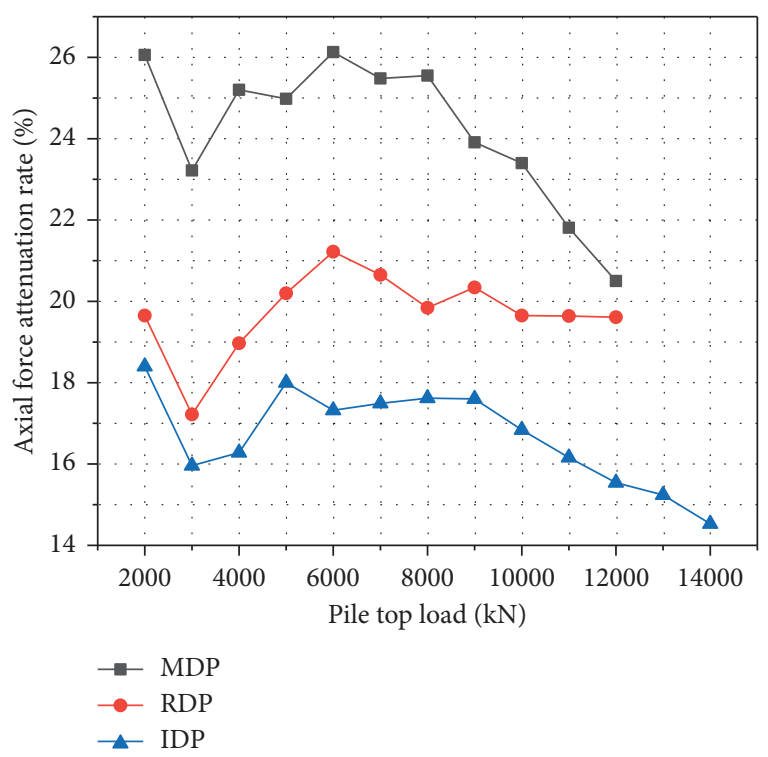

FIgURE 10: The axial force attenuation rate of test piles.

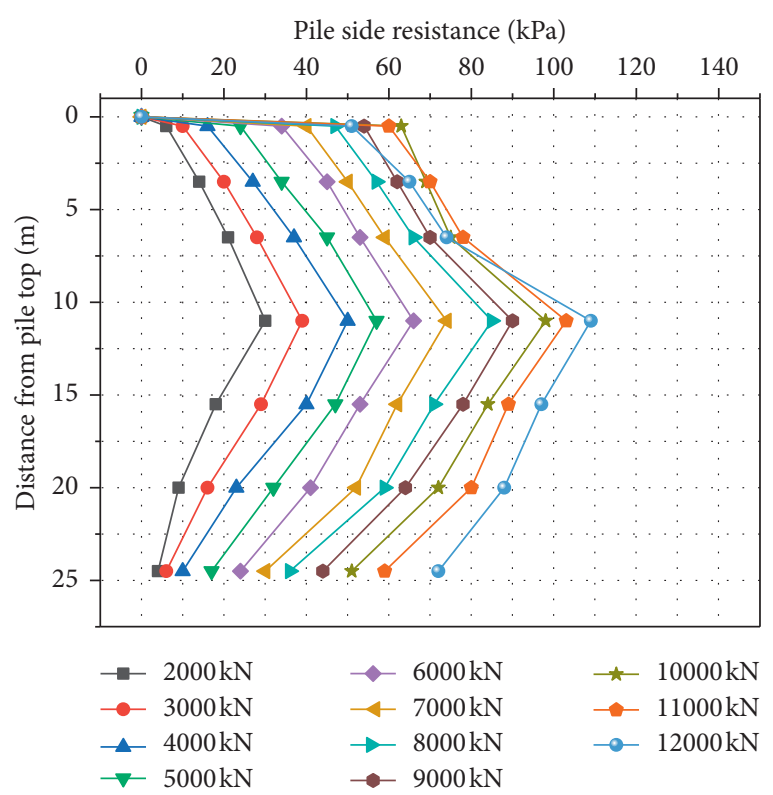

FIGURE 11: Pile side resistance of MDP.

However, when the pile settlements are larger than $10 \mathrm{~mm}$, especially larger than $15 \mathrm{~mm}$, pile end resistance of IDP is significantly larger than that of RDP and MDP when the pile settlements are the same.

\subsection{The Relationship between Pile End Resistance and Pile Side} Resistance. For 3 test piles under different loads, pile side resistances and pile end resistances are all shown in Figure 18 , and the ratios of every single resistance to the total resistance are shown in Figure 19. From Figure 18, it is noted that when the loads are applied at the top of every test pile, the line graphs of pile side resistance and pile end

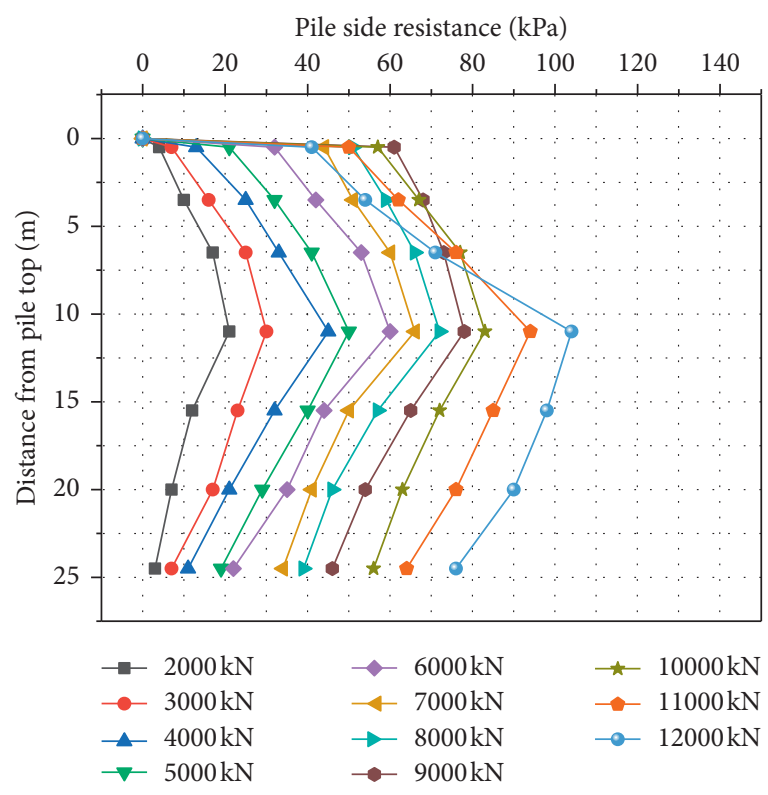

FIGURE 12: Pile side resistance of RDP.

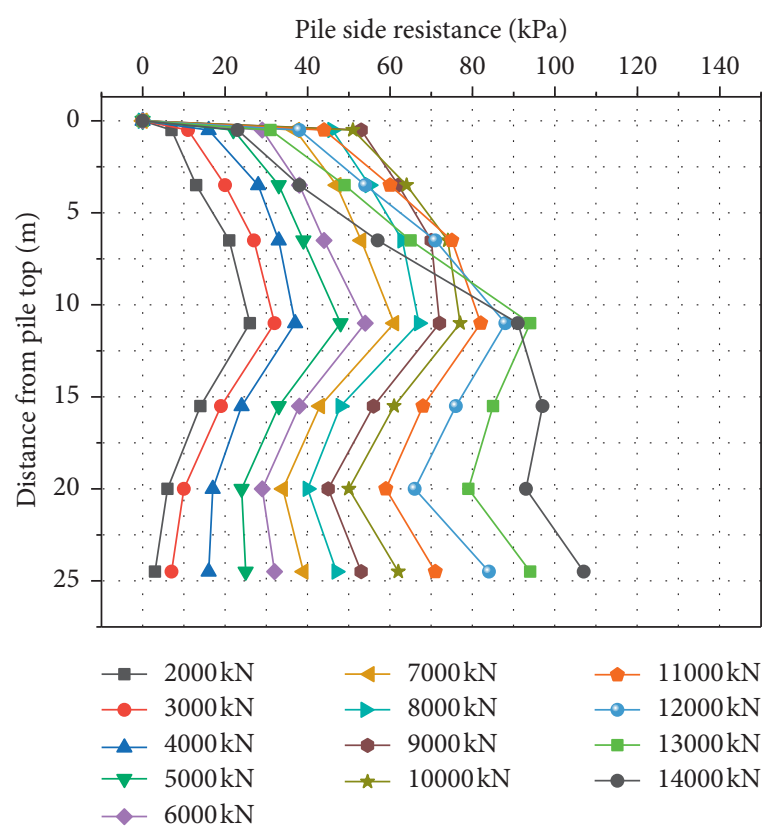

FIgURE 13: Pile side resistance of IDP.

resistance both show an ascending trend. And the continuous increase of the pile side resistance does not tend to a definite value, which suggests that pile side resistance does not reach the limit value after the first loading. In Section 5.1, the ultimate bearing capacity of MDP is $11000 \mathrm{kN}$, followed by RDP $(9000 \mathrm{kN})$ and IDP $(8000 \mathrm{kN})$, indicating that the pile side resistances of all test piles are not at the maximum state when the ultimate bearing capacity is reached.

From Figure 19, (1) pile side resistance ratio of MDP is the largest, while the ratio of pile end resistance is the smallest. (2) Pile side resistance ratio of IDP is the smallest, while the ratio of pile end resistance is the largest. But the 


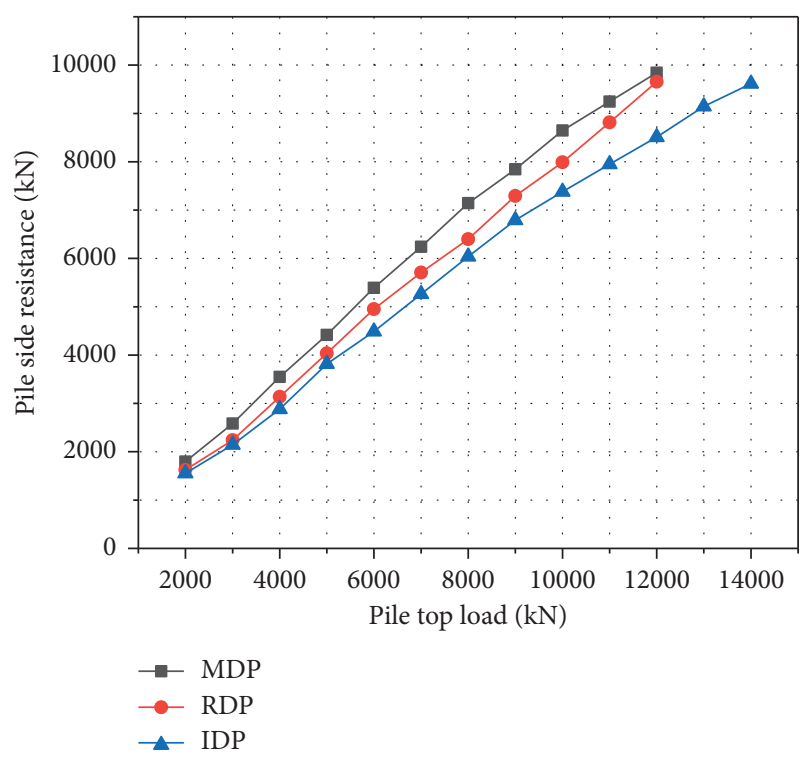

Figure 14: Pile side resistance of test piles under various loads.

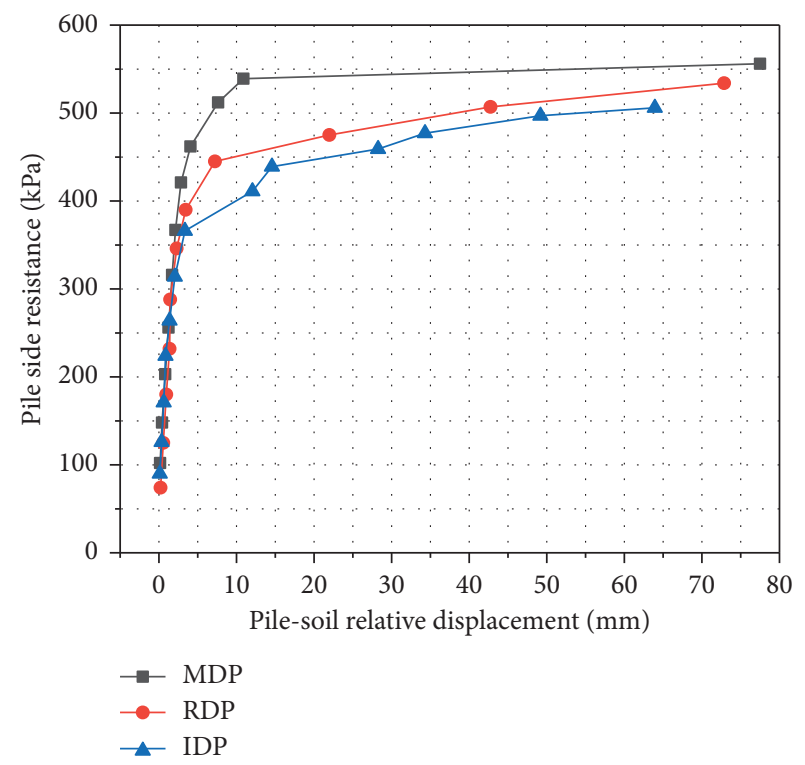

FIGURE 15: The relationship between pile side resistance and relative displacement of pile-soil.

variations of the 3 test piles are basically the same. At the later loading, pile side resistance ratios of these piles all show a decreasing trend, and the ratios of pile end resistance show an increasing trend, but the change trend is not obvious. The results suggest that the 3 test piles in this filed test are all friction piles, and pile side resistances and pile end resistances are not in the limit state at the last loading. During the early loading on the pile top, especially during the first loading and the second loading, the ratios of pile side resistances of the 3 test piles decrease, but the ratios of pile end resistances increase. The result indicates the complexity of the mechanical properties of the soil and the development of pile side resistance requires a process. Therefore, when

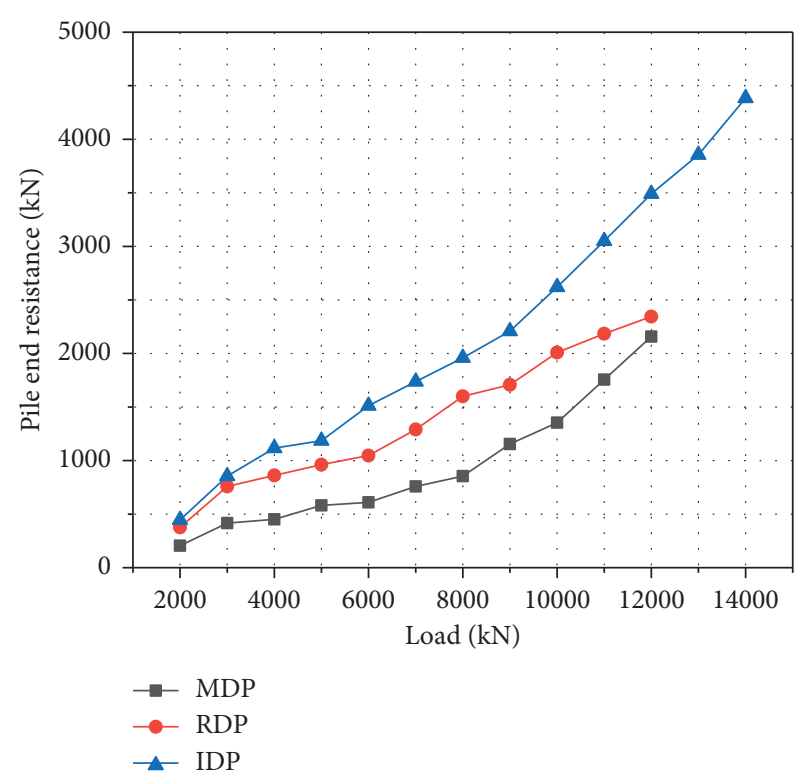

FIgURE 16: Pile end resistance of test piles under different loads.

designing cast-in-place piles in loess areas, it is necessary to consider the development degree of pile side resistance and pile end resistance and then use the different partial coefficients in pile side resistance and pile end resistance [58-63].

\section{Conclusions}

Through the full-scale field study, bearing characteristics of the 3 types of cast-in-place piles (MDP, RDP, and IDP) under different loads in loess area are studied in this paper. Based on the analysis of test results, the following conclusions can be drawn:

(1) Under the similar conditions, the ultimate bearing capacity of MDP is the largest $(11000 \mathrm{kN})$, followed by RDP $(9000 \mathrm{kN})$ and IDP $(8000 \mathrm{kN})$. All actual bearing capacities are larger than the estimated value $(7797.9 \mathrm{kN})$, which indicates that the pile bearing capacity estimated by the standard is conservative. The final settlement values of MDP, RDP, and IDP are $63.58 \mathrm{~mm}, 63.72 \mathrm{~mm}$, and $55.51 \mathrm{~mm}$; after unloading, the pile body rebound displacement of MDP is the largest $(13.91 \mathrm{~mm})$, followed by RDP $(9.15 \mathrm{~mm})$ and IDP $(8.14 \mathrm{~mm})$.

(2) The attenuation rates of axial force for piles (MDP, RDP, and IDP) are basically the same under the action of all levels of loading, all decreasing firstly and increasing finally. Among them, the rate of MDP is the largest (average is $24.2 \%$ ), followed by RDP (average is 19.72\%) and IDP (average is 16.69\%).

(3) The bearing capacity of all 3 test piles is mainly dependent on pile side resistances in loess area. Pile side resistance is not evenly distributed along the pile body, which is related to properties of soil around piles and pile-soil interactions. Under the same 
TABLe 4: Pile side and pile end resistance of test piles in ultimate bearing state.

\begin{tabular}{lcccccc}
\hline $\begin{array}{l}\text { Test } \\
\text { piles }\end{array}$ & $\begin{array}{c}\text { Ultimate bearing } \\
\text { capacity }(\mathrm{kN})\end{array}$ & $\begin{array}{c}\text { Pile side } \\
\text { resistance }(\mathrm{kN})\end{array}$ & $\begin{array}{c}\text { Pile side resistance } \\
\text { ratio }(\%)\end{array}$ & $\begin{array}{c}\text { Pile end } \\
\text { resistance }(\mathrm{kN})\end{array}$ & $\begin{array}{c}\text { Pile end resistance } \\
\text { ratio }(\%)\end{array}$ & $\begin{array}{c}\text { Pile end resistance/pile side } \\
\text { resistance }(\%)\end{array}$ \\
\hline MDP & 11000 & 9244 & 84 & 1756 & 16 & 19 \\
RDP & 9000 & 7292 & 81 & 1708 & 19 & 23.4 \\
IDP & 8000 & 6040 & 75.5 & 1960 & 24.5 & 32.5 \\
\hline
\end{tabular}

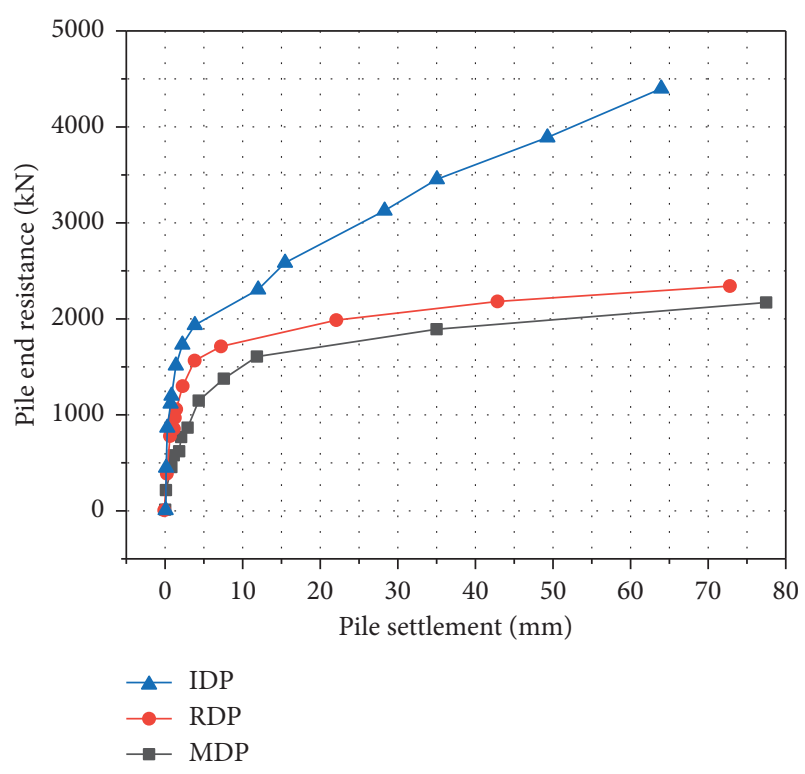

Figure 17: The change law of pile end resistance with pile settlement.

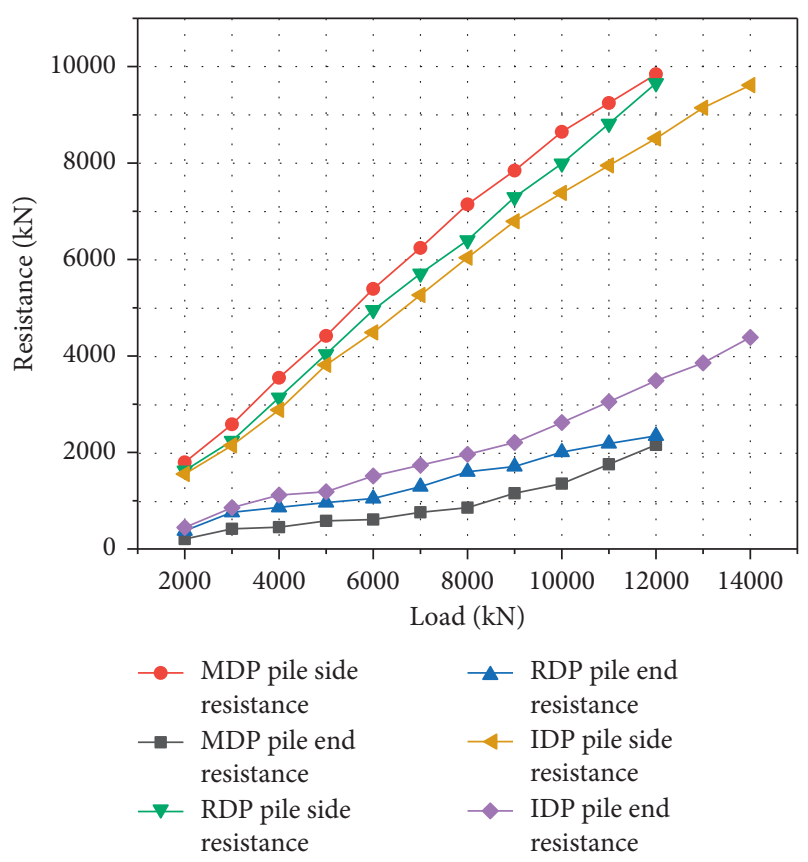

Figure 18: Test piles under different loads.

loads, pile side resistance of MDP is the largest, followed by RDP and IDP, while pile end resistances of the 3 test piles are opposite.

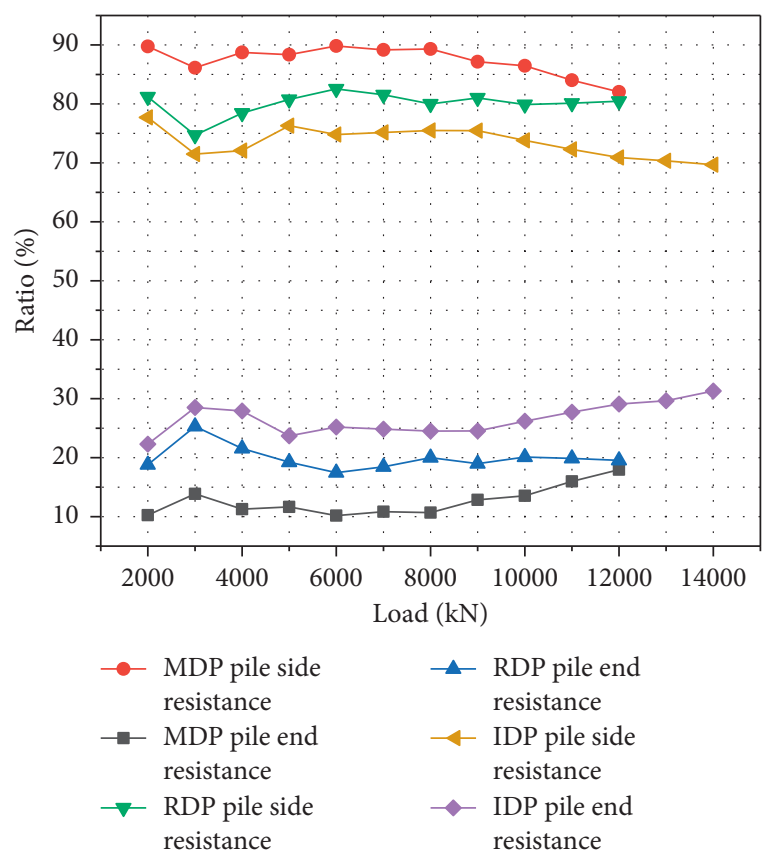

Figure 19: The ratios of every resistance to the total resistance.

(4) Hole-forming methods mainly influence the roughness of hole wall in loess area, which determines the value of pile side resistance. Compared with the impact drilling method, the other 2 methods (manual digging method and rotary drilling), especially manual digging method, have less disturbance to soil around the pile, resulting in rough hole wall and enhancing the pile-soil interactions.

(5) Different partial coefficients should be adopted rationally for pile side resistance and pile end resistance when designing cast-in-place piles in the loess area because pile side resistance and pile end resistance are not taking effect at the same time.

\section{Data Availability}

Data supporting this research article are available from the corresponding author on request.

\section{Conflicts of Interest}

The authors declare that they have no conflicts of interest.

\section{Acknowledgments}

The authors gratefully acknowledge the financial support by the National Key R\&D problem of China (no. 
2018YFC0808606) and the Project on Social Development of Shaanxi Provincial Science nos. 2018SF-378 and 2018SF-382. The authors also sincerely thank Rodney Sheldon Garnes who is a native speaker graduated from the University of the West Indies for his help in the language modification of this paper.

\section{References}

[1] G. Du, A. Wang, L. Li et al., "Calculation approach for lateral bearing capacity of single precast concrete piles with improved soil surrounds," Advances in Civil Engineering, vol. 2018, Article ID 5127927, 12 pages, 2018.

[2] X. Nie, X. Wei, X. Li et al., "Heat treatment and ventilation optimization in a deep mine," Advances in Civil Engineering, vol. 2018, Article ID 1529490, 12 pages, 2018.

[3] Z. Zhou, C. Ren, G. Xu, H. Zhan, and T. Liu, "Dynamic failure mode and dynamic response of high slope using shaking table test," Shock and Vibration, vol. 2019, Article ID 4802740, 19 pages, 2019.

[4] B. Lehane and F. Guo, "Lateral response of piles in cemented sand," Géotechnique, vol. 67, no. 7, pp. 1-11, 2017.

[5] M. T. Suleiman, T. Vande Voort, and S. Sritharan, "Behavior of driven ultrahigh-performance concrete H-piles subjected to vertical and lateral loadings," Journal of Geotechnical and Geoenvironmental Engineering, vol. 136, no. 10, pp. 14031413, 2010.

[6] M. Hamed and H. Canakci, "Experimental study on axial response of different pile materials in organic soil," Geomechanics and Engineering, vol. 12, no. 6, pp. 899-917, 2017.

[7] X. Luo, L. Niu, and S. Zhang, "An algorithm for traffic flow prediction based on improved SARIMA and GA," KSCE Journal of Civil Engineering, vol. 22, no. 10, pp. 4107-4115, 2018.

[8] Q. Yan, H. Chen, W. Chen et al., "Dynamic characteristic and fatigue accumulative damage of a cross shield tunnel structure under vibration load," Shock and Vibration, vol. 2018, Article ID 9525680, 14 pages, 2018.

[9] X. Weng, Y. Zhao, Y. Lou et al., "Application of fiber bragg grating strain sensors to a centrifuge model of a jacked pile in collapsible loess," Geotechnical Testing Journal, vol. 39, no. 3, article 20150076, 2016.

[10] Z. J. Zhou, S. S. Zhu, X. Kong, J. T. Lei, and T. Liu, "Optimization analysis of settlement parameters for post-grouting piles in loess area of Shaanxi, China," Advances in Civil Engineering, vol. 2019, Article ID 7085104, 11 pages, 2019.

[11] Z. Zhang, H. Zhang, Y. Tan, and H. Yang, "Natural wind utilization in the vertical shaft of a super-long highway tunnel and its energy saving effect," Building and Environment, vol. 145, pp. 140-152, 2018.

[12] X. Cheng and W. Jing, "Calculation models and stability of composite foundation treated with compaction piles," Geomechanics and Engineering, vol. 13, no. 6, pp. 929-946, 2017.

[13] Y. Fang, Z. Yao, G. Walton, and Y. Fu, "Liner behavior of a tunnel constructed below a caved zone," KSCE Journal of Civil Engineering, vol. 22, no. 10, pp. 4163-4172, 2018.

[14] P. Li, F. Wang, and Q. Fang, "Undrained analysis of ground reaction curves for deep tunnels in saturated ground considering the effect of ground reinforcement," Tunnelling and Underground Space Technology, vol. 71, pp. 579-590, 2018.

[15] J. Lai, X. Wang, J. Qiu et al., "A state-of-the-art review of sustainable energy based freeze proof technology for coldregion tunnels in China," Renewable and Sustainable Energy Reviews, vol. 82, pp. 3554-3569, 2018.
[16] J. Lai, S. He, J. Qiu et al., "Characteristics of seismic disasters and aseismic measures of tunnels in Wenchuan earthquake," Environmental Earth Sciences, vol. 76, no. 2, p. 94, 2017.

[17] X. Wu, H. Chu, and L. Wang, "Comparative research on lower bound depth of collapse loess," Proceedings of the Institution of Civil Engineers-Geotechnical Engineering, vol. 169, no. 1, pp. 67-72, 2016.

[18] N. L. Zotsenko and Y. L. Vinnikov, "Long-term settlement of buildings erected on driven cast-in-situ piles in loess soil," Soil Mechanics and Foundation Engineering, vol. 53, no. 3, pp. 189-195, 2016.

[19] J. Wang, Z. Song, B. Zhao, X. Liu, J. Liu, and J. Lai, “A study on the mechanical behavior and statistical damage constitutive model of sandstone," Arabian Journal for Science and Engineering, vol. 43, no. 10, pp. 5179-5192, 2018.

[20] Z.-Z. Qian, X.-L. Lu, W.-Z. Yang, and Q. Cui, "Behaviour of micropiles in collapsible loess under tension or compression load," Geomechanics and Engineering, vol. 7, no. 5, pp. 477493, 2014.

[21] Y. Li, S. Xu, H. Liu et al., "Displacement and stress characteristics of tunnel foundation in collapsible loess ground reinforced by jet grouting columns," Advances in Civil Engineering, vol. 2018, Article ID 2352174, 16 pages, 2018.

[22] S.-J. Feng, Z.-M. Shi, Y. Shen, and L.-C. Li, "Elimination of loess collapsibility with application to construction and demolition waste during dynamic compaction," Environmental Earth Sciences, vol. 73, no. 9, pp. 5317-5332, 2015.

[23] J. Rücknagel, G. Dumbeck, T. Harrach, E. Höhne, and O. Christen, "Visual structure assessment and mechanical soil properties of re-cultivated soils made up of loess," Soil Use and Management, vol. 29, no. 2, pp. 271-278, 2013.

[24] J. Lai, S. Mao, J. Qiu et al., "Investigation progresses and applications of fractional derivative model in geotechnical engineering," Mathematical Problems in Engineering, vol. 2016, Article ID 9183296, 15 pages, 2016.

[25] J. Lai, K. Wang, J. Qiu et al., "Vibration response characteristics of the cross tunnel structure," Shock and Vibration, vol. 2016, Article ID 9524206, 16 pages, 2016.

[26] S. Park, D. Lee, H.-J. Choi, K. Jung, and H. Choi, "Relative constructability and thermal performance of cast-in-place concrete energy pile: coil-type GHEX (ground heat exchanger)," Energy, vol. 81, pp. 56-66, 2015.

[27] H. Xing, Z. Zhang, H. Liu, and H. Wei, "Large-scale tests of pile-supported earth platform with and without geogrid," Geotextiles and Geomembranes, vol. 42, no. 6, pp. 586-598, 2014.

[28] A. W. Stuedlein, W. J. Neely, and T. M. Gurtowski, "Reliability-based design of augered cast-in-place piles in granular soils," Journal of Geotechnical and Geoenvironmental Engineering, vol. 138, no. 6, pp. 709-717, 2012.

[29] C. Akgüner and M. Kirkit, "Axial bearing capacity of socketed single cast-in-place piles," Soils and Foundations, vol. 52, no. 1, pp. 59-68, 2012.

[30] J. Lai, J. Qiu, H. Fan et al., "Fiber bragg grating sensors-based in-situ monitoring and safety assessment of loess tunnel," Journal of Sensors, vol. 2016, Article ID 8658290, 10 pages, 2016.

[31] J. Lai, H. Liu, J. Qiu et al., "Settlement analysis of saturated tailings dam treated by CFG pile composite foundation," Advances in Materials Science and Engineering, vol. 2016, Article ID 7383762, 10 pages, 2016.

[32] Z. Wang, Y. Xie, J. Qiu et al., "Field experiment on soaking characteristics of collapsible loess," Advances in Materials 
Science and Engineering, vol. 2017, Article ID 6213871, 17 pages, 2017.

[33] M. Sakr, "Comparison between high strain dynamicField experiment on soaking characteristics of collapsible loess and static load tests of helical piles in cohesive soils," Soil $D y$ namics and Earthquake Engineering, vol. 54, pp. 20-30, 2013.

[34] M. Y. Abu-Farsakh, M. N. Haque, and C. Tsai, "A full-scale field study for performance evaluation of axially loaded largediameter cylinder piles with pipe piles and PSC piles," Acta Geotechnica, vol. 12, no. 4, pp. 753-772, 2017.

[35] J. Qiu, H. Liu, J. Lai et al., "Investigating the long-term settlement of a tunnel built over improved loessial foundation soil using jet grouting technique," Journal of Performance of Constructed Facilities, vol. 32, no. 5, article 04018066, 2018.

[36] J. Qiu, X. Wang, S. He, H. Liu, J. Lai, and L. Wang, "The catastrophic landside in Maoxian county, Sichuan, SW China, on June 24, 2017," Natural Hazards, vol. 89, no. 3, pp. 1485-1493, 2017.

[37] X. Z. Li, X. L. Qu, C. Z. Qi, and Z. S. Shao, “A unified analytical method calculating brittle rocks deformation induced by crack growth," International Journal of Rock Mechanics and Mining Sciences, vol. 113, pp. 134-141, 2019.

[38] Y. Shang, F. Niu, X. Wu, and M. Liu, "A novel refrigerant system to reduce refreezing time of cast-in-place pile foundation in permafrost regions," Applied Thermal Engineering, vol. 128, pp. 1151-1158, 2018.

[39] S. Park, S. Lee, K. Oh, D. Kim, and H. Choi, "Engineering chart for thermal performance of cast-in-place energy pile considering thermal resistance," Applied Thermal Engineering, vol. 130, pp. 899-921, 2018.

[40] J. Lai, H. Liu, J. Qiu et al., "Stress analysis of CFG pile composite foundation in consolidating saturated mine tailings dam," Advances in Materials Science and Engineering, vol. 2016, Article ID 3948754, 12 pages, 2016.

[41] F. M. Abdrabbo and N. A. Ali, "Behaviour of single pile in consolidating soil," Alexandria Engineering Journal, vol. 54, no. 3, pp. 481-495, 2015.

[42] X. Li and L. Li, "Quantification of the pore structures of Malan loess and the effects on loess permeability and environmental significance, Shaanxi Province, China: an experimental study," Environmental Earth Sciences, vol. 76, no. 15, 2017.

[43] Z. Hu, K. Du, J. Lai et al., "Statistical analysis of influence of cover depth on loess tunnel deformation in NW China," Advances in Civil Engineering, vol. 2019, Article ID 2706976, 12 pages, 2019.

[44] T. Sprafke and I. Obreht, "Loess: rock, sediment or soil-what is missing for its definition?," Quaternary International, vol. 399, pp. 198-207, 2016.

[45] Z. Liu, F. Liu, F. Ma et al., "Collapsibility, composition, and microstructure of loess in China," Canadian Geotechnical Journal, vol. 53, no. 4, pp. 673-686, 2016.

[46] F. Zhang, R. Kong, and J. Peng, "Effects of heating on compositional, structural, and physicochemical properties of loess under laboratory conditions," Applied Clay Science, vol. 152, pp. 259-266, 2018.

[47] Y. Zhang, Y. Wang, N. Zhao et al., "Experimental and stressstrain equation investigation on compressive strength of raw and modified soil in loess plateau," Advances in Materials Science and Engineering, vol. 2016, Article ID 2681038, 10 pages, 2016.

[48] Profession Standard of The People's Republic of China, Technical Code for Building Pile Foundations (JGJ94-2008), China Architecture and Building Press, Beijing, China, 2008.
[49] Profession Standard of The People's Republic of China, Technical code for testing of building foundation piles (JGJ1062014), China Architecture and Building Press, Beijing, China, 2014.

[50] L. Gao, K. Yang, X. Chen, and X. Yu, "Study on the deformation measurement of the cast-in-place large-diameter pile using fiber bragg grating sensors," Sensors, vol. 17, no. 3, p. 505, 2017.

[51] J. Qiu, Y. Qin, J. Lai et al., "Structural response of the metro tunnel under local dynamic water environment in loess strata," Geofluids, vol. 2019, Article ID 8541959, 16 pages, 2019.

[52] H. Zhou, H. Liu, M. Randolph et al., "Experimental and analytical study of X-section cast-in-place concrete pile installation effect," International Journal of Physical Modelling in Geotechnics, vol. 17, no. 2, pp. 1-19, 2017.

[53] Z. Wang, S. Shen, W. Cheng et al., "Simple method to predict ground displacements caused by installing horizontal jetgrouting columns," Mathematical Problems in Engineering, vol. 2018, Article ID 1897394, 11 pages, 2018.

[54] S. Thiyyakkandi, M. Mcvay, P. Lai, and R. Herrera, "Suitability of jetted and grouted precast pile for supporting mast arm structures," Canadian Geotechnical Journal, vol. 54, no. 9, pp. 1231-1244, 2017.

[55] C.-W. Lee, Y.-S. Kim, and S.-Y. Park, "Development of prebored screw pile method and evaluation of its bearing characteristics," Marine Georesources and Geotechnology, vol. 34, no. 1, pp. 42-56, 2016.

[56] S. Suryasentana and B. Lehane, "Numerical derivation of CPT-based p-y curves for piles in sand," Geotechnique, vol. 64, no. 3, pp. 186-194, 2015.

[57] Q. Yan, Y. Xu, W. Zhang, P. Geng, and W. Yang, "Numerical analysis of the cracking and failure behaviors of segmental lining structure of an underwater shield tunnel subjected to a derailed high-speed train impact," Tunnelling and Underground Space Technology, vol. 72, pp. 41-54, 2018.

[58] X. L. Luo, D. Y. Li, Y. Yang, and S. R. Zhang, "Spatiotemporal traffic flow prediction with KNN and LSTM," Journal of Advanced Transportation, vol. 2019, Article ID 4145353, 10 pages, 2019.

[59] Z. Wang, Z. Hu, J. Lai et al., "Settlement characteristics of jacked box tunneling underneath a highway embankment," Journal of Performance of Constructed Facilities, vol. 33, no. 2, article 04019005, 2019.

[60] J. Qiu, X. Wang, J. Lai, Q. Zhang, and J. Wang, "Response characteristics and preventions for seismic subsidence of loess in Northwest China," Natural Hazards, vol. 92, no. 3, pp. 1909-1935, 2018.

[61] L. Wang, J. Sun, X. Huang et al., "A field testing study on negative skin friction along piles induced by seismic subsidence of loess," Soil Dynamics and Earthquake Engineering, vol. 31, no. 1, pp. 45-58, 2011.

[62] Y. W. Zhang, Z. P. Song, X. L. Weng, and Y. L. Xie, "A new soil-water characteristic curve model for unsaturated loess based on wetting-induced pore deformation," Geofluids, vol. 2019, Article ID 5261985, 13 pages, 2019.

[63] Y. W. Zhang, X. L. Weng, Z. P. Song, and Y. F. Sun, "Modeling of loess soaking induced impacts on metro tunnel using water soaking system in centrifuge," Geofluids, vol. 2019, Article ID 5487952, 13 pages, 2019. 


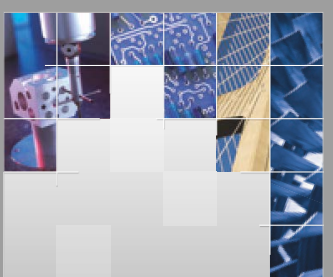

\section{Enfincering}
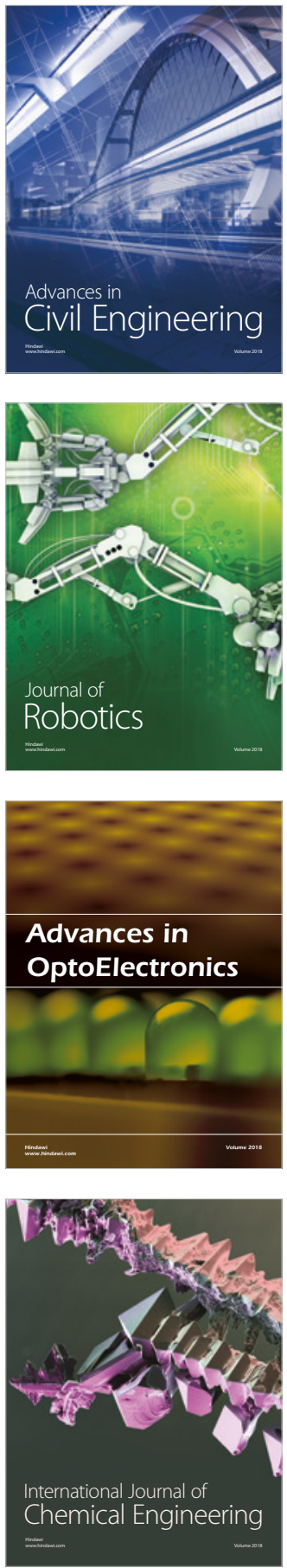

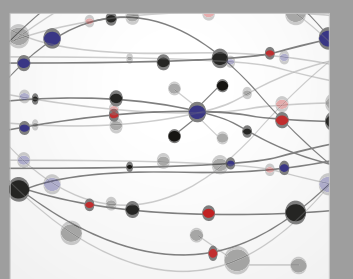

\section{Rotating \\ Machinery}

The Scientific World Journal

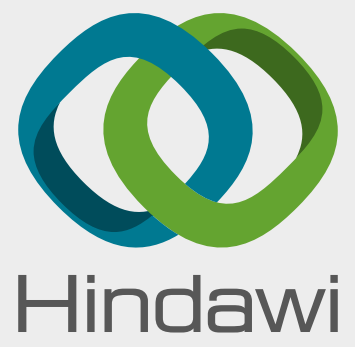

Submit your manuscripts at

www.hindawi.com
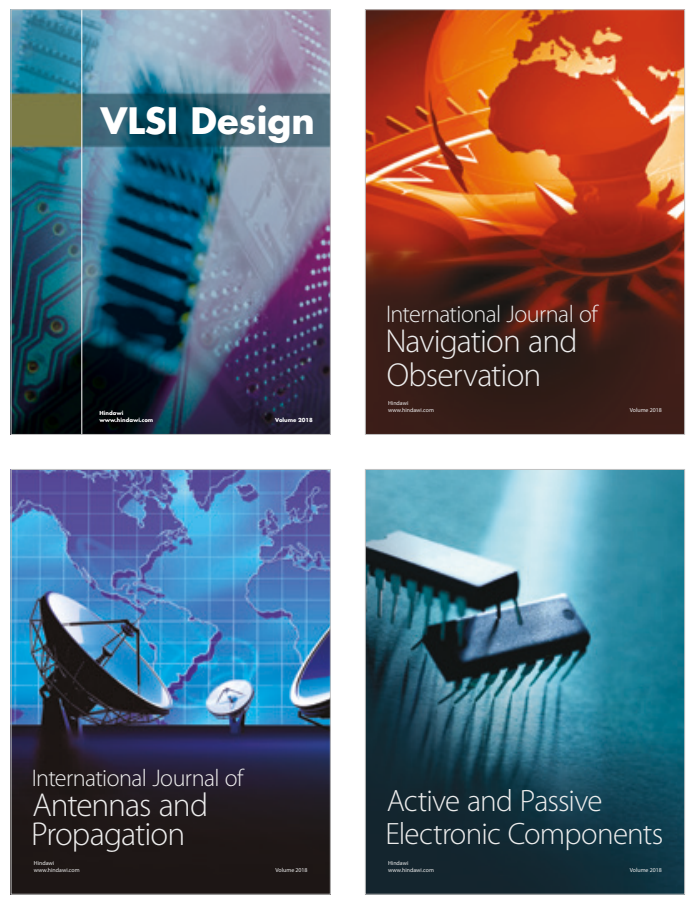
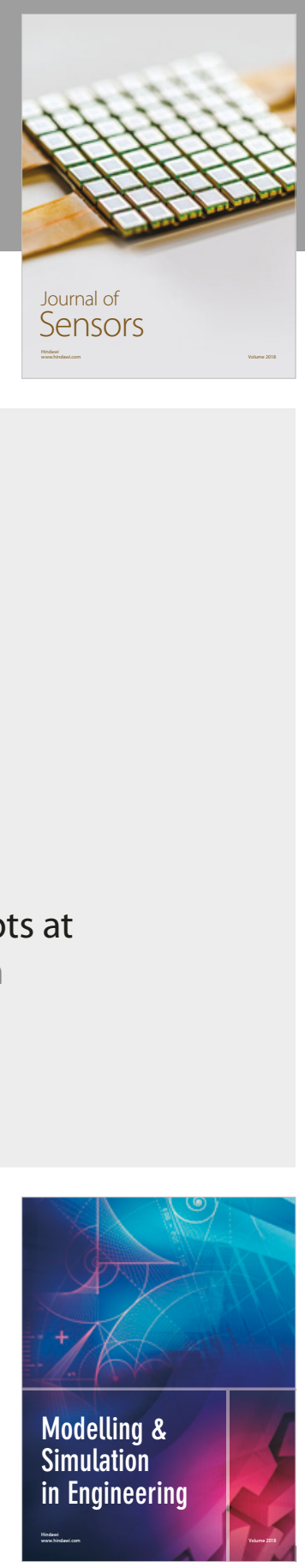

\section{Advances \\ Multimedia}
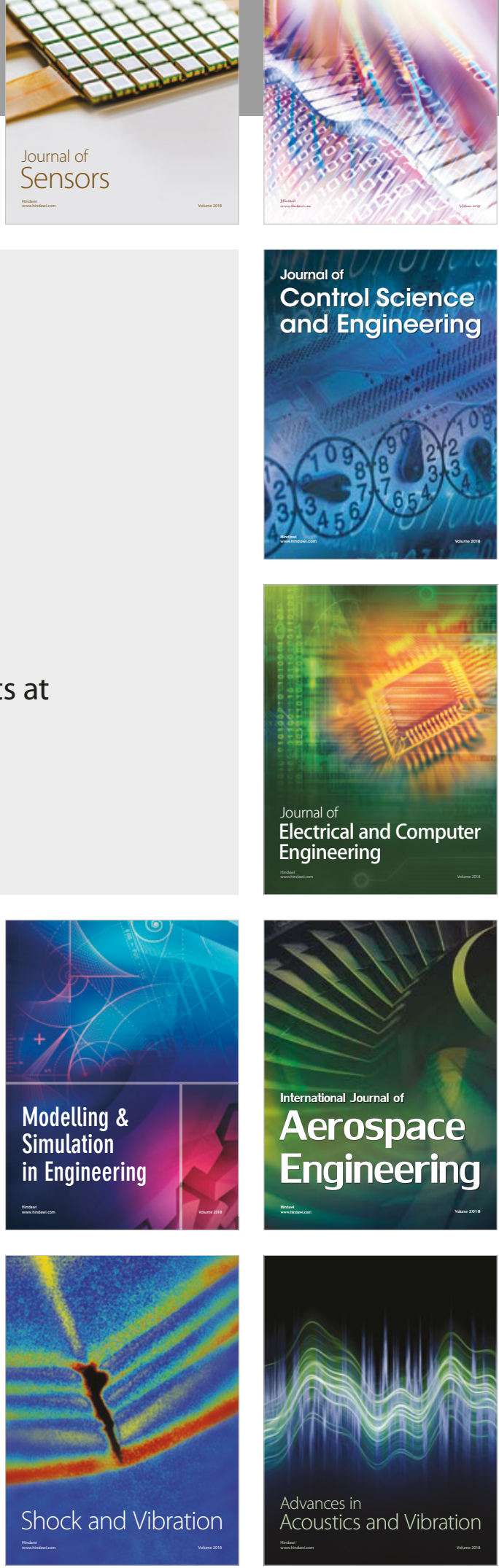